\title{
KEPASTIAN HUKUM HAK ATAS TANAH MELALUI PENDAFTARAN TANAH SISTEMATIS LENGKAP
}

\author{
Arif Tanri, Bambang Eko Turisno, Adya Paramita Prabandari \\ Program Studi Magister Kenotariatan \\ Fakultas Hukum, Universitas Diponegoro \\ Email: tanriarif@gmail.com
}

\begin{abstract}
The implementation of the Complete Systematic Land Registration Program encourages the role of Regency / City Land Offices not only as an institution that produces certificates of land rights, but at the same time helps land owners to obtain evidence of rights and empower land to improve welfare. Various problems also occur in land registration such as misinformation provided by the applicant. The approach method used in this study is the socio-legal approach. The results of this study are government policies in accelerating land registration through PTSL intended to provide legal certainty of land rights in the form of certificates for the community based on the principles of simple, fast, smooth, fair, equitable and open and accountable so as to improve the welfare and prosperity of the community and the country's economy and reduce and prevent land disputes and conflicts.
\end{abstract}

Keywords: Government Policy; PTSL

\begin{abstract}
Abstrak
Pelaksanaan Program Pendaftaran Tanah Sistematis Lengkap mendorong peran Kantor Pertanahan Kabupaten / Kota tidak hanya sekedar sebagai lembaga yang memproduksi sertipikat hak atas tanah, tapi sekaligus membantu pemilik tanah untuk bisa memperoleh alat bukti hak dan memberdayakan tanah guna meningkatkan kesejahteraan. Berbagai permasalahan juga terjadi dalam pendaftaran tanah seperti adanya kesalahan informasi yang diberikan oleh pihak pemohon, Metode pendekatan yang digunakan dalam penelitian ini adalah metode pendekatan socio-legal. Hasil penelitian ini adalah kebijakan pemerintah dalam mempercepat pendaftaran tanah melalui PTSL dimaksudkan untuk memberikan jaminan kepastian hukum Hak Atas Tanah berupa sertipikat bagi masyarakat berlandaskan asas sederhana, cepat, lancar, adil, merata dan terbuka serta akuntabel sehingga dapat meningkatkan kesejahteraan dan kemakmuran masyarakat dan ekonomi negara serta mengurangi dan mencegah sengketa dan konflik pertanahan.
\end{abstract}

\section{Kata Kunci: Kebijakan Pemerintah; Pendaftaran Tanah Sistematis Lengkap}

\section{A. Pendahuluan}

Tanah merupakan karunia Tuhan Yang Maha Esa bagi bangsa Indonesia yang dikuasai oleh Negara untuk kepentingan hajat hidup orang banyak, demi kesejahteraan seluruh rakyat Indonesia seperti ditegaskan dalam Undang Undang Dasar Negara Republik Indonesia Tahun 1945 (UUDNRI Tahun 1945) Pasal 33 ayat (3) yang menyatakan "Bumi dan air dan kekayaan alam yang terkandung di dalamnya dikuasai oleh Negara dan dipergunakan untuk sebesar-besar kemakmuran rakyat". Pasal tersebut mengandung arti bahwa negara bukan pemilik atas tanah tetapi hanya menguasai tanah (Suanda, 1991). 
Pendaftaran atas bidang tanah dilakukan agar mendapatkan kepastian hukum bagi pemegang hak atas tanah maupun pihak lain yang berkepentingan dengan tanah. Dengan telah melakukan pendaftaran dan mendapatkan sertifikat, pemegang hak atas tanah memiliki bukti yang kuat atas tanah tersebut. Undang-Undang Nomor 5 Tahun 1960 Tentang Peraturan Dasar Pokok-Pokok Agraria mengatur bahwa Pemerintah mengadakan pendaftaran Tanah di seluruh wilaya Republik Indonesia yang bertujuan untuk menjamin kepastian Hukum atas hak-hak atas tanah (Santoso 2010). Demikian dinyatakan juga fungsi sertifikat dalam Pasal 19 ayat (2) huruf c UUPA, karena itu, siapapun dapat dengan mudah membuktikan dirinya sebagai pemegang hak atas tanah bila telah jelas namanya tercantum dalam sertifikat itu. Selanjutnya dapat membuktikan mengenai keadaan-keadaan dari tanahnya itu misalnya luas, batas-batas, ataupun segala sesuatu yang berhubungan dengan bidang tanah dimaksud.

Praktik pensertipikatan tanah, terkadang terjadi perbedaan luas tanah yang tertera dalam sertipikat dengan kondisi faktual di lapangan. Hal ini terutama jika proses pensertifikatan tanah dilakukan secara sistemik (misal melalui Prona). Pelaksanaan pemberian sertipikat hak atas tanah dalam kerangka mencapai keadilan sosial, mengacu pada prinsip-prinsip negara kesejahteraan sebagaimana konsep negara kesejahteraan yaitu mengandung unsur sosialisme, mementingkan kesejahteraan di bidang politik maupun di bidang ekonomi (Ma'ruf ,2010).

Pendaftaran tanah secara sistematik diselenggarakan atas prakarsa pemerintah berdasarkan pada suatu rencana kerja jangka panjang dan Tahunan serta dilaksanakan di wilayah-wilayah yang ditetapkan oleh Menteri Negara Agraria/Kepala Badan Pertanahan Nasional. Pendaftaran tanah secara sistematik diutamakan, karena melalui cara ini mempercepat perolehan data mengenai bidang-bidang tanah yang akan didaftar daripada melalui pendaftaran tanah secara sporadik.

Pendaftaran Tanah Sistematis Lengkap yang selanjutnya disebut PTSL menjadi salah satu program prioritas nasional legalisasi aset yang ditetapkan Pemerintah sesuai dengan Peraturan Menteri Agraria dan Tata Ruang/Kepala Badan Pertanahan Nasional Republik Indonesia Nomor 12 Tahun 2017 yang dirubah dengan Peraturan Menteri Agraria Dan Tata Ruang/Kepala Badan Pertanahan Nasional Republik Indonesia Nomor 6 Tahun 2018 Tentang Percepatan Pendaftaran Tanah Sistematis Lengkap.

PTSL adalah Pendaftaran tanah di seluruh wilayah Republik Indonesia dalam satu wilayah desa/kelurahan, kegiatan pendaftaran tanah untuk pertama kali yang dilakukan secara serentak bagi semua obyek atau nama lainnya yang setingkat dengan itu, yang meliputi 
pengumpulan dan penetapan kebenaran data fisik dan data yuridis mengenai satu atau beberapa obyek pendaftaran tanah untuk keperluan pendaftarannya.

Pemerintah menyelenggarakan PTSL yang merupakan kebijakan pemerintah di bidang pertanahan untuk memperlancar kegiatan pendaftaran tanah di Indonesia. PTSL tersebut merupakan program lanjutan sebelumnya yaitu PRONA sebagai perwujudan program Catur Tertib di Bidang Pertanahan, sehingga program sertipikat hak atas tanah secara massal dapat memberikan jaminan kepastian hukum bagi penguasaan dan pemilikan tanah sebagai tanda bukti yang kuat.

Sertipikat hak atas tanah melalui PTSL yang diutamakan adalah kelancaran prosesnya tanpa mengabaikan kecermatan dan ketelitian, kehati-hatian dan keakuratan dalam penanganannya, sehingga terwujud kepastian hukum hak-hak atas tanah. Sertipikat hak atas tanah memberikan jaminan kepastian hukum atas bidang tanah yang dimilikinya, meminimalisir terjadinya sengketa, konflik dan perkara pertanahan.

Pandangan Aristoteles tentang keadilan bisa didapatkan dalam karyanya nichomachean ethics, politics, dan rethoric. Spesifik dilihat dalam buku nicomachean ethics, buku itu sepenuhnya ditujukan bagi keadilan, yang, berdasarkan filsafat hukum Aristoteles, mesti dianggap sebagai inti dari filsafat hukumnya, "karena hukum hanya bisa ditetapkan dalam kaitannya dengan keadilan" (Apeldoorn, 1996).

Pada pokoknya pandangan keadilan ini sebagai suatu pemberian hak persamaan tapi bukan persamarataan. Aristoteles membedakan hak persamaanya sesuai dengan hak proposional. Kesamaan hak dipandangan manusia sebagai suatu unit atau wadah yang sama. Inilah yang dapat dipahami bahwa semua orang atau setiap warga negara dihadapan hukum sama. Kesamaan proposional memberi tiap orang apa yang menjadi haknya sesuai dengan kemampuan dan prestasi yang telah dilakukanya.

Untuk memperjelas dan membatasi permasalahan yang ada dalam penulisan ini, maka rumusan masalah yang dianggap relevan dan sesuai dengan tujuan penulisan ini adalah: 1) Bagaimana kebijakan Pemerintah dalam mempercepat kepastian hukum Hak Atas Tanah melalui PTSL, 2) Bagaimana pelaksanaan kegiatan PTSL di Kantor Pertanahan Kota Jakarta Timur.

Fakta menunjukkan bahwa belum banyak hasil penelitian yang berkaitan dengan obyek penelitian baik dalam bentuk laporan, skripsi, tesis maupun disertasi. Namun khusus untuk 
penelitian hukum, dengan keterbatasan kemampuan penulis untuk menelusuri hasil-hasil penelitian di bidang hukum, ada beberapa penelitian tentang penerapan doktrin persamaan pada "Kepastian Hukum Hak Atas Tanah Melalui Pendaftaran Tanah Sistematis Lengkap (PTSL)"

Berdasarkan hasil penelusuran, penulis mendapat penelitian dalam bentuk jurnal yang ditulis oleh Prama Widianugraha di tahun 2019 dengan judul "Tinjauan Normatif Pendaftaran Tanah Sistematis Lengkap Dikaitkan Pembentukan Aturan Peraturan Perundang-Undangan”, yang mengungkapkan pokok permasalahan, yaitu: Bagaimana keberadaaan Peraturan Menteri Agraria Tata Ruang/Kepala Badan Pertanahan Nasional No.6 Tahun 2018 tentang Pendaftaran Tanah Sistematis Lengkap merupakan aturan Lex spesialis dari Peraturan Pemerintah Nomor 24 Tahun 1997 tentang Pendaftaran Tanah (Widianugraha, 2019).

Jurnal yang ditulis oleh Mira Novana Ardani pada tahun 2019 dengan judul "Peran Kantor Pertanahan dalam Kegiatan Pendaftaran Tanah Sistematis Lengkap" yang mengungkapkan permasalahan yaitu: bagaimana peran kantor pertanahan dalam kegiatan pendaftaran tanah sistematis lengkap (Ardani, 2019).

Jurnal yang ditulis oleh Sofi Alawiya, Kristiyanto, Anggit Wicaksono pada tahun 2019 dengan judul "Pelaksanaan Kegiatan Projek Percepatan Pelaksanaan Pendaftaran Tanah Sistematis Lengkap (PTSL) di Desa Sukobubuk Kecamatan Margorejo Kabupaten Pati” yang mengungkapkan permasalahan yaitu: Pertama, bagaimanakah pelaksanaan Kegiatan PTSL di Desa Sukobubuk Kecamatan Margorejo Kabupaten Pati. Kedua, apa hambatan dan solusi dalam pelaksanaan kegiatan PTSL di Desa Sukobubuk Kecamatan Margorejo Kabupaten Pati tersebut (Alawiya, Kristiyanto, and Wicaksono, 2019).

Artikel penelitian ini berbeda dengan penelitian yang sudah ada seperti di atas. Pada artikel ini lebih menekankan mengenai bagaimana kebijakan Pemerintah dalam mempercepat kepastian hukum Hak Atas Tanah melalui PTSL, dan bagaimana pelaksanaan kegiatan PTSL di Kantor Pertanahan Kota Jakarta Timur.

\section{B. Metode Penelitian}

Metode pendekatan yang digunakan adalah metode pendekatan socio-legal research, yang terdiri dari socio research dan legal research. Socio-legal research menurut Soerjono Soekanto merupakan "pemeriksaan yang mendalam terhadap fakta sosial untuk kemudian mengusahakan suatu pemecahan atas permasalahan yang timbul dalam gejala yang bersangkutan." (Marzuki, 2008) Penelitian ini bersifat deskritif analitis karena memberikan 
data yang seteliti mungkin tentang suatu gejala sosial atau fenomena yang terjadi di dalam kehidupan masyarkat dengan cara hanya memaparkan fakta-fakta secara sistematis, sesuai dengan kebutuhan dari penelitian (Dewata and Achmad, 2010).

\section{Hasil Dan Pembahasan}

\section{Kebijakan Pemerintah Dalam Mempercepat Kepastian Hukum Hak Atas Tanah Melalui PTSL}

Kantor Pertanahan adalah instansi vertikal dari Menteri Agraria dan Tata Ruang/Badan Pertanahan Nasional RI di Kabupaten/Kota yang berada di bawah dan bertanggungjawab kepada Menteri ATR/BPN RI melalui Kepala Kantor Wilayah Badan Pertanahan Nasional. Kantor Pertanahan berada di wilayah kabupaten/kotamadya, yang melakukan pendaftaran hak atas tanah dan pemeliharaan daftar umum pendaftaran tanah.

Landasan organisasi Kantor Pertanahan Kota Jakarta Timur berdasarkan Peraturan Menteri Agraria Dan Tata Ruang/Kepala Badan Pertanahan Nasional Republik Indonesia Nomor 38 Tahun 2016 Tentang Organisasi Dan Tata Kerja Kantor Wilayah Badan Pertanahan Nasional Dan Kantor Pertanahan, yang diperkuat juga dengan Peraturan Presiden Nomor 20 Tahun 2015 Tentang Badan Pertanahan Nasional, serta memperhatikan Surat Persetujuan Menteri Pendayagunaan Aparatur Negara dan Reformasi Birokrasi Nomor B/2976.1/M.PANRB/8/2016 perihal Usulan Penataan Kantor Wilayah dan Kantor Pertanahan di lingkungan Badan Pertanahan Nasional (BPN).

PTSL adalah proses pendaftaran tanah untuk pertama kali, yang dilakukan secara serentak bagi semua obyek Pendaftaran Tanah di seluruh wilayah Republik Indonesia dalam satu wilayah desa atau kelurahan atau nama lainnya yang setingkat dengan itu. Melalui program ini, pemerintah memberikan jaminan kepastian hukum atau hak atas tanah yang dimiliki masyarakat. Metode PTSL ini merupakan inovasi pemerintah melalui Kementerian ATR/BPN untuk memenuhi kebutuhan dasar masyarakat: sandang, pangan, dan papan. Program tersebut dituangkan dalam Peraturan Menteri Agraria dan Tata Ruang/Kepala Badan Pertanahan Nasional No.6 Tahun 2018 Tentang Percepatan Pendaftaran Tanah Sistematis Lengkap dan Instruksi Presiden No.2 Tahun 2018 tentang Percepatan Pendaftaran Tanah Sistematis Lengkap di Seluruh Wilayah Republik Indonesia.

Sebagai gambaran, jika menggunakan metode pendaftaran tanah sporadis, maka maksimum pencapaian target per Tahun adalah hanya 1 juta bidang tanah, yang artinya 
untuk menyelesaikan 75 juta bidang diperlukan waktu 75 Tahun. Sementara melalui program PTSL, target pendaftaran 75 juta bidang tanah itu dapat diselesaikan dalam kurun waktu 9 Tahun dan diharapkan selesai pada Tahun 2025.

Didasarkan pada prioritas program strategis Kementerian Agraria dan Tata Ruang/Badan Pertanahan Nasional (ATR/BPN), Kementerian ATR/BPN, mengadakan program pendaftaran tanah sistematis lengkap (PTSL).

Penyelenggaraan pendaftaran sertipikat hak atas tanah melalui kegiatan PTSL di Kantor Pertanahan Kota Jakarta Timur, dilaksanakan melalui kegiatan pendaftaran tanah untuk pertama kali yang dilakukan secara serentak bagi semua obyek pendaftaran tanah di seluruh wilayah Republik Indonesia dalam satu wilayah desa/kelurahan atau nama lainnya yang setingkat dengan itu, yang meliputi pengumpulan dan penetapan kebenaran data fisik dan data yuridis mengenai satu atau beberapa obyek Pendaftaran Tanah untuk keperluan pendaftarannya. (Lubis and Lubis, 2003) PTSL adalah kegiatan yang diselenggarakan oleh pemerintah di bidang pertanahan pada umumnya dan di bidang pendaftaran hak atas tanah pada khususnya.

Percepatan pendaftaran tanah dengan metode PTSL merupakan pelaksanaan amanat Pasal 33 A ayat (3) UUD 1945 serta Pasal 2 dan 19 UU Nomor 5 Tahun 1960. Penerapan metode PTSL, merupakan jalan percepatan agar di Tahun 2025 seluruh bidang tanah di Indonesia terdaftar. Pelaksana dalam pengimplementasian PTSL diharapkan dapat memenuhi kualitas dalam artian semua azas, prinsip, maupun metodologi tidak ada yang terlewati. Selain itu PTSL merupakan percepatan dari metode business as usual yang selama ini sudah dilaksanakan.

Kebijakan hukum pertanahan pada sistem kepastian hukum Kepemilikan Hak atas Tanah yang melebihi batas maksimal ini, bukan merupakan suatu karya seni yang adanya hanya untuk dinikmati oleh orang-orang yang mengamatinya. Ia juga bukan suatu hasil kebudayaan (walaupun UUPA bersumber dari hukum adat) yang adanya hanya untuk menjadi bahan pengkajian secara logis-rasional. Hukum diciptakan untuk dijalankan. "hukum yang tidak pernah dijalankan, pada hakikatnya telah berhenti menjadi hukum", demikian menurut Satjitpto Rahardjo yang dikutip dari Scholten. Kemudian dalam memberikan penjelasan tentang hukum pertanahan, khususnya mengenai pelaksanaan kebijakan pertanahan dalam bidang kepastian hukum kepemilikan hak atas tanah ini (Wignjodipuro, 1982). 
Kebijakan hukum pertanahan pada sistem pendaftaran sertipikat hak atas tanah melalui PTSL ini, bukan merupakan suatu karya seni yang adanya hanya untuk dinikmati oleh orang-orang yang mengamatinya. Ia juga bukan suatu hasil kebudayaan (walaupun UUPA bersumber dari hukum adat) yang adanya hanya untuk menjadi bahan pengkajian secara logis-rasional (Handoko, 2014).

Pendaftaran sertipikat hak atas tanah melalui kegiatan PTSL, dilaksanakan melalui pendaftaran tanah pertama kali secara sistematik, yaitu kegiatan pendaftaran tanah pertama kali yang dilakukan secara serentak yang meliputi semua objek pendaftaran yang belum didaftar dalam wilayah atau bagian wilayah suatu desa/kelurahan. Pendaftaran tanah secara sistematik diselenggarakan atas prakarsa pemerintah didasarkan pada suatu rencana kerja jangka panjang dan Tahunan serta dilaksanakan di wilayah-wilayah yang ditetapkan oleh Menteri Agraria dan Tata Ruang/Kepala Badan Pertanahan Nasional.

Pemerintah dalam menyelenggarakan pendaftaran sertipikat hak atas tanah dilaksanakan dengan mengingat keadaan negara dan masyarakat, keperluan lalu lintas sosial ekonomi serta kemungkinan penyelenggaraannya, menurut pertimbangan Menteri Agraria dan Tata Ruang/Kepala Badan Pertanahan Nasional, kegiatan PTSL menggunakan anggaran dari APBN. Rangkaian kegiatan pendaftaran sertipikat hak atas tanah oleh pemerintah (dilaksanakan oleh BPN), dalam penyelenggaraannya dibantu oleh pejabat lain. Pendaftaran secara sistematik juga memanfaatkan keuntungan dari skala besar dan akan lebih murah serta lebih cepat dari pendaftaran secara sporadik.

Kebijakan Pemerintah yang diterapkan dalam pelaksanaan PTSL mampu memberikan rasa keadilan, kepastian hukum dan kemanfaatan. PTSL memberikan ruang dan kesempatan yang sama bagi setiap warga negara untuk berperan aktif didalamnya dan output dari kegiatan tersebut mampu memberikan kepastian hukum akan kepemilikan tanahnya dan memberikan manfaat lebih untuk hidup dan kehidupannya.

\section{Pelaksanaan Kegiatan PTSL di Kantor Pertanahan Kota Jakarta Timur}

\section{a. Perencanaan Kegiatan PTSL}

Legalisasi aset masyarakat melalui PTSL didasarkan target kegiatan PTSL yang ditetapkan setiap Tahun anggaran sesuai dengan jumlah alokasi anggaran yang diterima oleh Kementerian Agraria dan Tata Ruang/Badan Pertanahan Nasional. Dalam rangka perencanaan penetapan subyek dan obyek program legalisasi aset masyarakat melalui PTSL serta supaya dapat memenuhi target penyelesaian tepat 
waktu dan tepat sasaran, maka Kepala Kantor Pertanahan Kota Jakarta Timur membuat perencanaan secara sistematis dengan melakukan pra inventarisasi calon lokasi dan calon peserta.

\section{b. Sasaran Kegiatan PTSL}

Kepala Kantor Pertanahan menetapkan lokasi kegiatan PTSL di wilayah kerjanya, penetapan lokasi dapat dilakukan dalam satu wilayah desa/kelurahan atau secara bertahap bagian demi bagian dalam satu hamparan. Penetapan lokasi dilakukan dengan ketentuan : berdasarkan ketersediaan anggaran khusus PTSL yang telah dialokasikan dalam APBN/APBD; diprioritaskan pada lokasi desa/kelurahan yang ada kegiatan PRONA/PRODA, dana desa,lintas sektor, massal swadaya masyarakat, corporate social responsibility (CSR) dan/atau program pendaftaran tanah massal lainnya, atau berdasarkan ketersediaan dana yang sah sesuai dengan ketentuan peraturan perundang-undangan untuk 1 (satu) desa/kelurahan PTSL; mempertimbangkan ketersediaan peta kerja, ketersediaan dan kemampuan optimal pelaksana PTSL pada masing-masing Kantor Pertanahan. Dalam hal lokasi yang ditetapkan terdiri dari beberapa desa/kelurahan, diupayakan agar desa/kelurahan yang menjadi obyek PTSL letaknya berdekatan.

Sesuai dengan target dari Presiden RI dalam Tahun 2017 untuk PTSL sebesar 5 juta bidang seluruh Indonesia. Pelaksanaan PTSL dilakukan dengan tahapan:

1) Perencanaan dan persiapan;

2) Penetapan lokasi kegiatan PTSL;

3) Pembentukan dan penetapan Panitia Ajudikasi PTSL;

4) Penyuluhan;

5) Pengumpulan Data Fisik dan Data Yuridis bidang tanah;

6) Pemeriksaan tanah;

7) Pengumuman Data Fisik dan data Yuridis bidang tanah serta pembuktian hak;

8) Penerbitan keputusan pemberian atau pengakuan Hak atas tanah;

9) Pembukuan dan penerbitan Sertipikat Hak Atas Tanah;

Penetapan obyek lokasi PTSL dilakukan secara cermat dan teliti sesuai dengan kriteria PTSL yang telah ditentukan. Penetapan lokasi kegiatan PTSL hendaknya memperhatikan hasil-hasil dari program pertanahan yang ada di Kantor Pertanahan Kota Jakarta Timur pada Tahun sebelumnya.

Sesuai Pasal 26 Peraturan Menteri Agraria dan Tata Ruang/Kepala Badan Pertanahan 
Nasional Republik Indonesia Nomor 12/2017 Tentang Percepatan Pendaftaran Tanah Sistematis Lengkap, bidang tanah yang dapat diterbitkan Sertipikat Hak Atas Tanahnya (Kategori 1) diberikan kepada:

1) Perorangan Warga Negara Indonesia;

2) Masyarakat yang termasuk dalam Program Pemerintah Bidang Perumahan Sederhana;

3) Badan hukum keagamaan dan badan hukum sosial yang sesuai antara perutukan dan penggunaan tanahnya;

4) PNS, Pensiunan PNS, TNI, Purnawirawan TNI, POLRI, Purnawirawan POLRI, dan suami / istri / janda / duda veteran / pensiunan PNS/ Purnawirawan TNI/Purnawirawan POLRI;

5) Instansi Pemerintah dan Pemerintah Daerah, untuk melaksanakan tugas dan fungsinya dan tidak bersifat profit;

6) Nadzir;

7) Masyarakat Hukum Adat;

Persyaratan yang menjadi kewajiban peserta kegiatan PTSL antara lain:

(a) Menyediakan/menyiapkan alas hak/alat bukti perolehan tanah yang akan dijadikan dasar pendaftaran tanah sesuai ketentuan yang berlaku;

(b) Menunjukkan letak dan batas-batas tanah yang dimohon (dapat dengan kuasa);

(c) Memasang patok tanda batas tanah;

Pelaksanaan pendaftaran sertipikat hak atas tanah melalui PTSL mengharuskan pengangkatan pejabat sebagaimana ditentukan di dalam peraturan hukum tersebut. Kedua, harus ada orang- orang yang melakukan perbuatan yang berkaitan dengan pertanahan. Ketiga, orang-orang tersebut mengetahui adanya peraturan tentang keharusan bagi mereka untuk menghadapi pegawai yang telah ditentukan untuk mencatatkan peristiwa tersebut. Keempat, bahwa orang-orang itu bersedia pula untuk berbuat demikian. Dengan demikian produk akhir dari kegiatan PTSL dapat memberikan kepastian hukum bagi pemegang haknya serta memberi jaminan kepastian hukum dari pihak pihak yang beritikat tidak baik terhadap kepemilikan tanahnya (Supriadi, 2007).

Ruang lingkup kegiatan PTSL yang memberikan kesempatan kepada seluruh penduduk Indonesia untuk turut serta didalamnya tanpa membedakan status tanah baik yang sudah terdaftar maupun belum terdaftar, yang bersengketa maupun tidak bersengketa dapat dipandang memberikan rasa keadilan bagi seluruh masarakat. Pada akhirnya kegiatan PTSL produk akhirnya memberikan nilai lebih terhadap pemanfaatan lahan baik untuk kehidupan 
personal maupun kemajuan daerah.

\section{Simpulan}

Kebijakan pemerintah dalam mempercepat pendaftaran tanah melalui PTSL dimaksudkan untuk memberikan jaminan kepastian hukum Hak Atas Tanah berupa sertipikat bagi masyarakat berlandaskan asas sederhana, cepat, lancar ,adil, merata dan terbuka serta akuntabel sehingga dapat meningkatkan kesejahteraan dan kemakmuran masyarakat dan ekonomi negara serta mengurangi dan mencegah sengketa dan konflik pertanahan . Kebijakan pemerintah dalam mempercepat kepastian hukum hak atas tanah melalui PTSL di Kota Jakarta Timur didasarkan fakta bahwa tahun 2016 tanah yang sudah bersertifikat seluas 13.834,46 hektare, sedang jumlah bidang tanah yang belum bersertifikat pada 281.126 bidang. Total luas tanah yang sudah bersertifikat baru 53,73 persen dari total keseluruhan bidang tanah di Kota Jakarta Timur. Sehingga perlu dilakukan kebijakan dari pemerintah dalam hal ini Kementerian Agraria dan Tata Ruang/Badan Pertanahan Nasional (ATR/BPN), Kementerian ATR/BPN, mengadakan program pendaftaran tanah sistematis lengkap (PTSL). Pendaftaran sertipikat hak atas tanah melalui kegiatan PTSL, dilaksanakan melalui pendaftaran tanah pertama kali secara sistematik. Sertipikat hak atas tanah melalui kegiatan PTSL dilaksanakan untuk menciptakan kepastian hukum atas bidang tanah di Indonesia.

Pelaksanaan Kegiatan PTSL di Kantor Pertanahan Kota Jakarta Timur dimulai dengan melakukan perencanaan kegiatan PTSL yang sistematis oleh Kepala Kantor Pertanahan Kota Jakarta Timur dengan melakukan pra inventarisasi calon lokasi dan calon peserta. Kegiatan PTSL dimaksudkan untuk semua tanah yang ada di Indonesia yang dimiliki secara perseorangan maupun yang berbadan hukum. PTSL dilaksanakan dengan beberapa agenda yang meliputi penentuan panitia ajudikasi PTSL, penyuluhan kemudian dengan proses pensertipikatan Hak Atas Tanah, dilanjutkan dengan proses pemeriksaan tanah yang meliputi pengumuman data fisik maupun yuridis dari bidang tanah beserta pembuktian hak dan berakhir dengan diterbitkannya Keputusan Pemberian Hak Atas Tanah.

\section{DAFTAR PUSTAKA}

Apeldoorn, L. J. V. (1996). Pengantar Ilmu Hukum. Cetakan Kedua Puluh Enam. Jakarta: Pradnya Paramita. 
Dewata, Muktifajar Nur, And Yulianto Achmad. (2010). Dualisme Penelitian Hukum Normatif Dan Empiris. Yogyakarta: Pustaka Pelajar.

Handoko, W. (2014). Kebijakan Hukum Pertanahan, Sebuah Refleksi Keadilan Hukum Progresif. Yogyakarta: Thafa Media.

Lubis, Mhd. Yamin, And Lubis, Abd. Rahim. (2003). Hukum Pendaftaran Tanah. Bandung: Mandar Maju.

Ma'ruf, U. (2010). Politik Hukum Di Bidang Pertanahan. Semarang: Badan Penerbit Universitas Diponegoro.

Marzuki, P. M. (2008). Penelitian Hukum. Cet. 2. Jakarta: Kencana.

Santoso, U. (2010). Hukum Agraria Dan Hak-Hak Atas Tanah. Cetakan Ke-6. Jakarta: Prenada Media Group.

Suanda, I.W. (1991). Hukum Pertanahan Indonesia. Jakarta: Rineka Cipta.

Supriadi. (2007). Hukum Agraria. Jakarta: Sinar Grafika.

Wignjodipuro, S. (1982). Pengantar Dan Asas-Asas Hukum Adat. Jakarta: Gunung Agung.

Alawiya, Sofi, Kristiyanto, And Anggit Wicaksono. (2019). "Pelaksanaan Kegiatan Projek

Percepatan Pelaksanaan Pendaftaran Tanah Sistematis Lengkap (PTSL) Di Desa Sukobubuk Kecamatan Margorejo Kabupaten Pati,” April. Https://Doi.Org/10.24176/Sk.V19i1.3217.

Ardani, Mira Novana. (2019). "Peran Kantor Pertanahan Dalam Kegiatan Pendaftaran Tanah Sistematis Lengkap.” Gema Keadilan 6 (1): 44-62.

Widianugraha, Prama. (2019). "Tinjauan Normatif Pendaftaran Tanah Sistematis Lengkap Dikaitkan Pembentukan Aturan Peraturan Perundang-Undangan.” Jurnal Bina Mulia Hukum 3 (2): 208-23. Https://Doi.Org/10.23920/Jbmh.V3n2.17.

Undang Undang Dasar Negara Republik Indonesia Tahun 1945.

Undang-Undang Nomor 5 Tahun 1960 Tentang Peraturan Dasar Pokok-Pokok Agraria.

Peraturan Presiden Nomor 20 Tahun 2015 Tentang Badan Pertanahan Nasional.

Peraturan Mentri Agraria Dan Tata Ruang/Kepala Badan Pertanahan Nasional Republik Indonesia

Nomor 38 Tahun 2016 Tentang Organisasi Dan Tata Kerja Kantor Wilayah Badan Pertanahan Nasional Dan Kantor Pertanahan.

Peraturan Menteri Agraria Dan Tata Ruang/Kepala Badan Pertanahan Nasional Republik Indonesia Nomor 6 Tahun 2018 Tentang Percepatan Pendaftaran Tanah Sistematis Lengkap. 